\title{
Ad skepticisms: Antecedents and consequences
}

\author{
Rafique Ahmed Khuhro ${ }^{a^{*}}$, Asad Khan ${ }^{b}$, Asad Afzal Humayon ${ }^{c}$ and Abdul Salam Khuhro ${ }^{d}$
}

${ }^{a}$ Assistant Professor at University of Hairpur, Department of Management Sciences, University of Haripur, Hattar Road, Haripur, Pakistan

${ }^{b}$ Lecturer at University of Hairpur, Department of Management Sciences, University of Haripur, Hattar Road, Haripur, Pakistan

${ }^{c}$ Assistant Professor at CIIT Vehari, Department of Management Sciences, CIIT Vehari, Peer Murad, Vehari, Pakistan

${ }^{d}$ Research Scholar at CIIT Vehari, Department of Management Sciences, CIIT Vehari, Peer Murad, Vehari, Pakistan

\section{H R O N I C L E}

Article history:

Received: October 1, 2016

Received in revised format: No-

vember 16, 2016

Accepted: November 16, 2016

Available online:

November 20, 2016

Keywords:

Customer Disengagement

Cynicism

Reactance

Self-Esteem

Ad Skepticism

\section{Introduction}

Companies are trying to have their customers engaged either online or offline (Brodie et al., 2011), or its boasting the engagement and loyalty programs are introduced (Hollebeek, 2011). Yet they have to face the disengaged customers (Goode, 2012). There can be many reasons of it, such as service failure, environmental and industrial condition, competition and internal policies of the company. Currently, many efforts are taken for increasing the engagement (Hollebeek, 2012), on the contrary customers are saved from the disengagement. Very thin literature is available on the customer disengagement (Goode,

\footnotetext{
* Corresponding author.

E-mail address: rafique.khuhro@uoh.edu.pk (R. A. Khuhro)

(C) 2017 Growing Science Ltd. All rights reserved.

doi: $10.5267 /$ j.msl.2016.11.005
} 
2012), and there is no any study which has considered the ad skepticism as the main role playing variable to customer disengagement. Ad skepticism is sub divided into three categories, General Ad Skepticism, Social Ad Skepticism and International Ad Skepticism. In our study International Ad Skepticism is not studied, because our unit of analysis is mobile phone service providers in Pakistan, which is not linked with the international business. Customer disengagement is still an unexplored area. A handsome work is done in the area of moral disengagement (Aquino et al., 2007); somewhat in employee disengagement (Pech \& Slade, 2006); attentional disengagement (Blakely et al., 2012), and academic disengagement (Foley, 2004). Table one is given to display the definitions of disengagement in other areas of studies. Our conceptual definition is "The level of a customer's physical, cognitive and emotional absence in their relationship with a service organization." As per our definition customer can disengage from the service organization physically when he or she leave interacting with a service provider. Customer may disengage by not indulging him to any cognitive process while getting or leaving the services and the last one is emotional disengagement which is related with the customer estrangement with the brand.

Table 1

Definitions of disengagement in other areas of study

\begin{tabular}{|c|c|c|}
\hline Authors & Construct & Definition \\
\hline Kahn, 1990 & Personal Disengagement & $\begin{array}{l}\text { The uncoupling of selves from work roles and "in disen- } \\
\text { gagement, people withdraw and defend themselves physi- } \\
\text { cally, cognitively, or emotionally during role perfor- } \\
\text { mances" }\end{array}$ \\
\hline $\begin{array}{l}\text { Major \& Schmader, } \\
1998\end{array}$ & Academic Disengagement & $\begin{array}{l}\text { The detachment of self-esteem from external feedback, } \\
\text { such that feelings of self-worth are not dependent on suc- } \\
\text { cesses or failures in that domain }\end{array}$ \\
\hline Bandura, 2002 & Moral Disengagement & $\begin{array}{l}\text { Moral disengagement is a set of socio cognitive processes } \\
\text { through which people can disengage from humane acts and } \\
\text { instead commit inhumane, harassing, harming, or horrible } \\
\text { actions against other people. }\end{array}$ \\
\hline Pech \& Slade, 2006 & Employee Disengagement & $\begin{array}{l}\text { A phenomenon where employees are at work but are mini- } \\
\text { mizing their work contribution }\end{array}$ \\
\hline
\end{tabular}

Some authors argue that disengagement is universal and must come in human life in any part of life with any behavior. Disengagement has different forms and can occur in different timings. Form mean; it can be social disengagement, an employee disengagement from job, a student disengagement from studies, disengagement from family, disengagement from material possession, or a customer disengagement from goods or services (Asimakopoulos \& Dix, 2013). Same as customers can also go into the different forms of disengagement such as start leaving the possession of product/service or leave the stimulation process in getting services.

While others argue that all humans are not influenced by disengagement and it is not a universal (Hofstede, 2006; Lay et al., 2013). Their argument is that disengagement is intrinsic and extrinsic; it is influenced by personality traits and other factors such as social behavior or economic conditions. Disengagement may change with the social possession of a person, a student may not disengage while entering in to professional life can lead him to the disengagement (Reijmersdal et al., 2013).

Moral disengagement is more intensive form in the service sector, it comes under the social cognitive theory, and it is defined as the "set of socio-cognitive processes through which people can disengage from humane acts and instead commit inhumane, harassing, harming, or horrible actions against other people" (Thornberg \& Jungert, 2013). The case of Telenor in Pakistan is the best example, when people disengaged morally from the Telenor services due the blasphemous act of a Norway citizen (PakTribune, 2005). 
A finance manager has to provide the report of disengagement in financial institutions if any customer is lost, because of this account managers try to stop this divorce and work for long term relationship. However this is not the case with a poor customer, usually low revenue customers are not involved in retention programs (Perrien et al., 1995). This is not the case in telecom sector in Pakistan; low revenue generating customers are as included in the retention programs as the high revenue customers. However they are not rewarded as are the high revenue customers, particular lower customer segments such as bronze and silver and young customer is focused with the concern that they are more tend to initiating the relationship instead of disengagement in relationship with very small benefits (Haenlein \& Kaplan, 2009). By this companies become to have more range of live subscribers and they can claim the largest subscriber holder in the industry.

Bank policies are as well the factor of disengagement (Perrien et al., 1995), same is the case in telecom sector, customer is not so mature and well educated to understand their policies ads and it encourages the customer disengagement either physically, cognitively or emotionally. The policies are not clear enough for consumers, they are not informed in their best interests, hidden charges are applied and they are not discussed in the advertising. Subscription charges are discussed in ads however un-subscription or daily charges are not communicated. All this leads to customer unhappy relations with the service provider due to ad disbeliefs, because of this there is need to understand clearly the role of ad skepticism, either general or social to customer disengagement which is the purpose of this research work.

\section{Literature Review}

\subsection{Cynicism}

Cynicism is studied in many disciplines with different context, such as interpersonal and personality studies, organization and behavior of employee, social and political (Chylinski \& Chu, 2010). Consumer cynicism is a process of related cognitive, behavioral, and affective reactions expressed by initial suspicion, defensive attempts, and eventual alienation of the consumer (Chylinski \& Chu, 2010). Cynicism is defined as "the suspicion of other people's motives, faithfulness, and goodwill" (Kanter \& Wortzel, 1985) and it is linked directly to the believability of advertising claims (Obermiller et al., 2005; Thakor \& Goneau-Lessard, 2009)

Cynicism refers to "disbelief in the possibility of the good" (Berman, 1997) Consumers intend to achieve the desired ends with the availing services or consuming goods; they may achieve the goal or face the failure. When they find failure in achieving that ends with the help of provided information in ads they tend to fall in cynicism (Campbell \& Kirmani, 2000) which leads to ad skepticism. More cynicism is found in government in urban markets (Newman et al., 1995) Economic insecurity also creates the cynicism (Berman, 1997)

Those individuals who are highly involved, they tend to face more cynicism than those who are less involved. Negative messages for the competitors can also increase the level of cynicism because of the increase in the inconsistencies the minds of individuals (Lau, 1985). This suspiciousness leads a customer to ad skepticism which is our first hypothesis.

\section{H1a: Cynicism has positive effect on Ad Skepticism}

Developing countries places more emphasis on education for economic development but simultaneously it increases the cynicism with the adaptation of more knowledge (Morris, 2011). Macaskill (2007) has studied the age effect and cynicism and has found that older the age, more the likelihood of cynicism. Cynicism can contribute to apathy (Lau, 1985), which even do not let individual to think for society before the disengagement, because of this we hypotheses that cynicism has positive effect on the social ad skepticism.

H1b: Cynicism has positive effect on Social Ad Skepticism 


\subsection{Self-Esteem}

Self-esteem is a general attitude towards oneself and it is assumed to be a positive or negative orientation toward oneself (Gana et al., 2013). Self-esteem is a stronger determinant of educational attainment for males than females (de Araujo \& Lagos, 2012). Self-esteem can be implicit and explicit, implicit is considered as the automatic while explicit is reflective (Aquino et al., 2007). Self-esteem is considered as the product of intuitive, automatic process of affective experiences which is somehow influenced by social interactions. While explicit self-esteem is achieved through conscious and rational processing of self-relevant information (Blakely et al., 2012). The implicit self-esteem can be altered but not the explicit (Foley, 2004).

High self-esteem is and indicator of optimal functioning and it usually becomes the antecedent of productivity and happiness but yet the relation is not found, either it may be in casual or formal relationship between psychological well-being and self-esteem (Pech \& Slade, 2006). In an study of universal reactance, higher self-esteem among adolescents is related to higher levels of (commercial) ad skepticism (Boush et al., 1994). Individual self and information given to him usually contradict which creates disbelieves (PakTribune, 2005), same is in the case of information given in the ads which contradicts with the self leads towards the ad skepticism; either general ad skepticism or social ad skepticism, which are our hypothesis two a and b.

H2a: Self-esteem has positive effect on Ad Skepticism

H2b: Self-esteem has positive effect on Social Ad Skepticism

\subsection{Reactance}

Reactance is defined as a motivational state directed toward the re-establishment of the threatened or eliminated freedoms, which should manifest itself in an increased desire to engage in the relevant behavior or actual attempts to engage in it (Brehm, 1966). Reactance is commonly understood to be a response elicited when an individual's choices are restricted or eliminated. Reactance theory places the importance of individual freedom and in this condition where consumers react against threats for their freedoms. Here freedom is defined as a person's belief to be able to engage in a certain behavior and to decide on the type of behavior, as well as how it is performed and when (Brehm \& Brehm, 1981). This may differ in various regions of the world as east Asian participants reported significantly less reactance than Western Europeans (Jonas et al., 2009). Reactance theory predicts that persons who are convinced that a toll will come are more opposed than less convinced persons.

Consumers likely to have reactance with the products or services where they are strongly suggested due the reason of being restricted in their selection (Kwon \& Chung, 2010). Psychological reactance theory was originated by Brehm (1966) and it was refined and further elaborated by Brehm and Brehm (1981). This theory suggests that a motivation force is aroused to regain the loss of perceived freedom (Buboltz Jr et al., 2003). Generally people do not have direct control over the price or tariffs charged to them (Schade \& Baum, 2007) and in the case of Pakistani Telecom industry a large amount of government taxes are as well charged to them which is $15 \%$ advance tax and $19.5 \%$ GST. Service providers only ad their own charges while government taxes are not disclosed. Customers call them the extra and hidden charges which create a situation of customer reactance to the ads.

\section{H3a: Reactance has positive effect on Ad Skepticism}

On website pop-up ads usually crates reactance and same is the case of unsolicited advice, consumer ignore these types of recommendations, even they are for the welfare of society. Consumer psychological reactance is tempted in the sales promotional activities as customer is asked to select a low value option, or the charity promotions (Lee \& Lee, 2009). This is same as our hypothesis three b which is: 
H3b: Reactance has positive effect on Social Ad Skepticism

\subsection{Ad Skepticism}

Ad Skepticism and general attitude towards advertising are two separate constructs (Obermiller \& Spangenberg, 1998) ; a considerable work has been conducted to investigate the attitudes towards business and advertising such as (Barksdale \& Darden, 1972); (Gaski \& Etzel, 1986); (Muehling, 1987). Ad skepticism is constrained to advertising and not for all kind of communications. It is also conceptualized as market place belief (Obermiller \& Spangenberg, 1998).

Skepticism toward advertising in general is defined as the tendency toward disbelief of advertising claims (Obermiller \& Spangenberg, 1998). These claims can be done through any medium such as TV, Radio, Web Ads or NEWS and Magazine.

Disbeliefs are transferred from one generation to second generation. Obermiller and Spangenberg (2000) worked on the intergenerational influences and determined ad skepticism as a separate construct from skepticism towards other sources of product information; their study found that children were less skeptical than their mothers. Older people are more skeptical, high correlation between advertising skepticism and sales people was also found, this may be as sales force is closely related with the company sales tactics.

Ad-brand incongruence can have both positive and negative effects in established and less established brands. Ad incongruence may occur when an advertiser communicates a message of a man in underwear ready for work or an ad of car in which a happy army is shown not the car. Advertising does not have negative effect to established brands rather it may be used to change consumers' brand schema and it also provides flexibility in brand knowledge structure. Ad linking plays vital role in ad credibility, while ad credibility has negative effect on ad-brand incongruences (Khuhro et al., 2015). High involvement products affect more on ad credibility. Incongruent ad brings novelty in brand communications but creates complexity in the advertising, which ultimately results skepticism (Dahlen et al., 2005).

Same way for reducing the complexity instead of introducing new brands, marketers try to market the brand extensions. There can be similar and dissimilar brand extensions but ad spending places positive effect on similar brand extensions. Dissimilar brand extensions lead to brand extensions skepticism due to heavy budgets on promotional campaigns. (Taylor \& Bearden, 2003). This is the reason that we purpose hypothesis that ad skepticism will lead to customer disengagement as disbeliefs remove the relation between a brand or service provider and customer.

\section{H4: Ad Skepticism has positive effect on Customer Disengagement}

Thakor and Goneau-Lessard (2009) studied the effects of peer influence, parental influence, and personality variables to the social advertising skepticism. Social ads are different than commercial, they try to discourage behaviors which are risky such as smoking and encourage behaviors which are effortful such as blood donations. Modest correlation was in their research between social ad skepticism and commercial ad skepticism; the authors have taken both construct as separate one, and same are taken separate in our research work.

Cause related marketing (CRM) is used by companies to increase their profits by giving some margins, i.e. Surf excel launched the campaign for special children. It also creates skepticism towards ad, particularly to cause related marketing ads. It is specially increased when sin industries try to promote CRM activities, this can be the case, if any Tabaco company raise funds for cancer. This CRM ad skepticism can be reduced by providing high level of knowledge in ads and using emotional ads instead of attention-getting ads (Singh, Kristensen, \& Villasenor, 2009). It is linked with our hypotheses that social ads which are out of customer thought process or unacceptable as per their values create the disengagement which is our sixth hypotheses. 
H5: Social Ad Skepticism has positive effect on Customer Disengagement

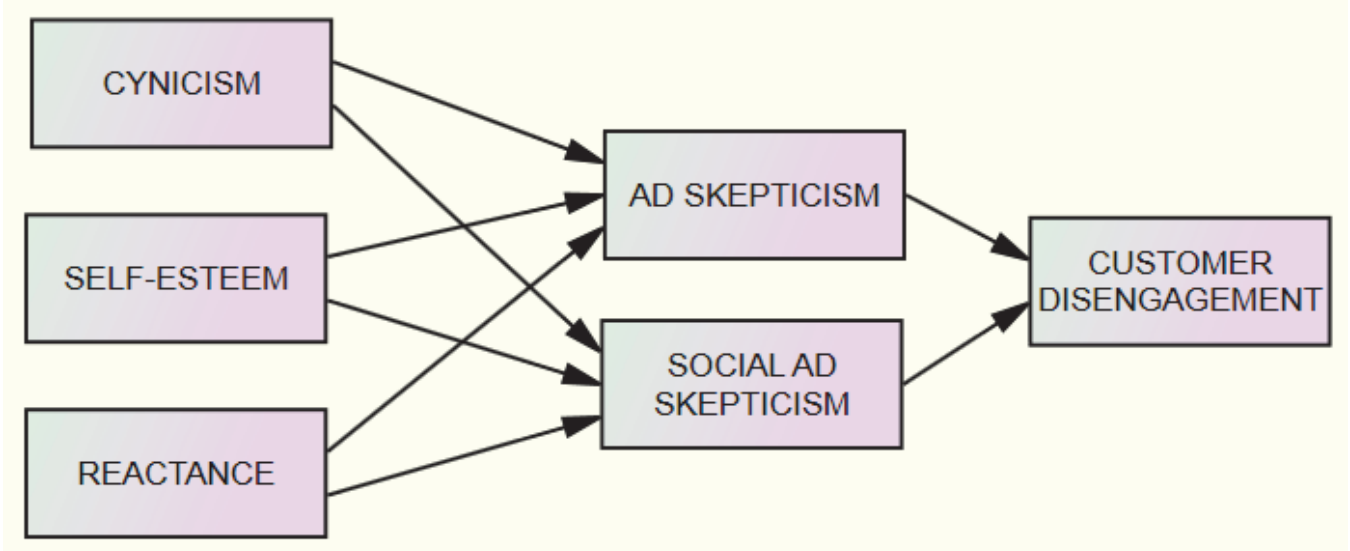

Fig. 1. Hypothetical Model

\section{Methodology}

This is an empirical study, which examines the Ad Skepticism effect on the Customer Disengagement and Ad Skepticism antecedents are tested which Cynicism, Reactance, and Self-image, these antecedents are used in previous research work (Obermiller \& Spangenberg, 1998; Thakor \& Goneau-Lessard, 2009) as common for general ad skepticism and social ad skepticism. Survey method was selected to collect the data from customers who visited for virtual currency services at telecom and banking branches by convenience sampling technique. The customers were surveyed in major cities of Pakistan which are Islamabad, Karachi, Lahore, Peshawar, Quetta, Sukkur, Multan and Faisalabad. The logic behind collecting data from visiting customers instead of general public or students is that they are having real experience of being engaged in brand or company and they were also aware of products and services advertising. The sample used in the study is three hundred and fifty seven. The area is divided into two broad categories which are urban and rural, the age is categorized into five groups, and the education is divided into three categories; a summary of it is given below table.

Table 1

\begin{tabular}{|c|c|c|c|c|c|c|c|c|c|}
\hline Gender & Frequency & Area & Frequency & Education & Freq. & Monthly Income & Freq. & Age & Freq. \\
\hline Male & 208 & Rural & 225 & Intermediate & 165 & Below 10000 & 74 & $<20$ Years & 64 \\
\hline \multirow[t]{4}{*}{ Female } & 149 & Urban & 128 & Under Graduation & 112 & 10,000 to 30,000 & 249 & $\begin{array}{l}21-30 \\
\text { Years }\end{array}$ & 74 \\
\hline & & & & Masters \& PhD & 80 & 31,000 to 60,000 & 24 & $\begin{array}{l}31-40 \\
\text { Years }\end{array}$ & 81 \\
\hline & & & & & & $>60,000$ & 10 & $\begin{array}{l}41-50 \\
\text { Years }\end{array}$ & 87 \\
\hline & & & & & & & & $>50$ Years & 51 \\
\hline
\end{tabular}

Tested instruments are used to measure the constructs which are Cynicism (Kanter \& Wortzel, 1985), it is having six items; Self-esteem (Kanter \& Wortzel, 1985), it is having ten items; Reactance (Donnell et al., 2001), it is having eighteen items; Ad skepticism (Obermiller \& Spangenberg, 1998), it is having nine items; Social ad skepticism (Thakor \& Goneau-Lessard, 2009), it is having eight items.

\section{Results}

First of all we conducted CFA in order to check the reliability and validity of the well-developed scale used in this study. Researchers used different types of fit indices for reporting the results of Structural 
Equation Modeling (SEM) but according to Schreiber et al., (2006), researcher decided to use four key fit indices, i.e., CMIN/df $<3$, Comparative Fit indices (CFI) $>0.90$, Tucker-Lewis Index (TLI) $>0.90$, and Root-Mean Square Error of Approximation (RMSEA) $<0.08$ and same threshold for fit indices was also suggested by Hameed et al. (2013). Therefore the confirmatory factor analysis was run for the measures of Cynicism (C), Self -Esteem (SE), Reactance (R), Ad Skepticism (AS), Social Ad Skepticism (SAD) and Customer Disengagement (CD). After running the CFA, the researcher found poor fit indices, but after viewing the factor loading of all measures of the constructs, researcher dropped one items of SE, five items of R, and one item of SAD one by one respectively due to the low factor loading (i.e., <.50) and then ran CFA again. According to the recommendation of Kline (2011) the standardized factor loadings of all the indicators were found above the threshold value, i.e., $>0.50$. The results were near to the suggested fit indices but after correlating the variances of measurement errors one by one having M. I value (i.e., $>10$ ), the results demonstrated the reasonable fit indices such as CMIN/df = 2.20, CFI $=0.92$, TLI $=0.91$ and RMSEA $=0.058$. Thus over all model showed the good fit indices.

The descriptive statistics and inter correlation summary of the variables are exhibited in table two.

Table 2

Correlation among Constructs and Demographic Variables

\begin{tabular}{|c|c|c|c|c|c|c|c|c|c|c|c|c|c|}
\hline & & Mean SD & 1 & 2 & 3 & 4 & 5 & 6 & 7 & 8 & 9 & 10 & 11 \\
\hline 1 & AGE & $1.95 \quad 0.26$ & & & & & & & & & & & \\
\hline 2 & SEX & NA NA & .003 & & & & & & & & & & \\
\hline 3 & AREA & 1.850 .35 & -.039 & .076 & & & & & & & & & \\
\hline 4 & EDUCATION & 2.330 .51 & $.251^{* *}$ & .008 & .031 & & & & & & & & \\
\hline 5 & Network & $2.57 \quad 1.40$ & .001 & -.012 & -.016 & .046 & & & & & & & \\
\hline 6 & $\mathrm{C}$ & 3.311 .06 & .055 & -.035 & -.032 & .050 & .026 & 0.94 & & & & & \\
\hline 7 & SE & $3.03 \quad 0.90$ & .004 & -.005 & .003 & -.021 & .053 & $823^{* *}$ & 0.95 & & & & \\
\hline 8 & $\mathrm{R}$ & 3.130 .94 & .028 & -.033 & -.063 & .061 & .042 & $.822^{* *}$ & $.821^{* *}$ & 0.93 & & & \\
\hline 9 & AS & 2.901 .01 & -.039 & .020 & -.015 & -.099 & .033 & $.604^{* *}$ & $.817^{* *}$ & $.656^{* *}$ & 0.92 & & \\
\hline 10 & SAD & 3.140 .95 & .015 & .007 & -.067 & .070 & .036 & $.794^{* *}$ & $.803^{* *}$ & $.850^{* *}$ & $604^{* *}$ & 0.90 & \\
\hline 11 & $\mathrm{CD}$ & 3.550 .95 & .055 & -.029 & -.063 & -.020 & .039 & $213^{* *}$ & .063 & $.243^{* *}$ & -.080 & $.217^{* *}$ & 0.75 \\
\hline
\end{tabular}

The researcher also checked the reliability, convergent validity and discriminant validity of the scale. As suggested by Hair et al. (2010), a scale have reliability when its composite reliability (CR) is greater than 0.70 , convergent validity when its average variance extracted greater than 0.50 and discriminant validity when maximum shared squared variances (MSV) and average shared squared variance (ASV) less than AVE. All constructs used in this study have the reliability, convergent validity and discriminant validity as exhibited in the Table 3.

Table 3

Reliability, Convergent Validity and Discriminant Validity

\begin{tabular}{lrrrr}
\hline Variables & CR & AVE & MSV & ASV \\
\hline Customer Disengagement & 0.75 & 0.50 & 0.06 & 0.03 \\
Cynicism & 0.94 & 0.72 & 0.68 & 0.48 \\
Social Ad Skepticism & 0.90 & 0.57 & 0.52 & 0.48 \\
Ad Skepticism & 0.92 & 0.60 & 0.45 & 0.37 \\
Reactance & 0.93 & 0.75 & 0.72 & 0.51 \\
Self Esteem & 0.95 & 0.70 & 0.68 & 0.53 \\
\hline CR = Composite Reliability; AVE = Average Variance Extracted; MSV = Maximum Shared Variance; ASV= Average Shared Variance
\end{tabular}

Unlike other studies researcher used SEM not only for confirmatory factor analysis but also used it for hypothesis testing through structural regression. The biggest advantage of SEM is that it has the ability to overcome the measurement error with in a statistical model because this cannot be done through multiple regressions. The results are shown in the following Table 3. 
Table 3

Regression Weights

\begin{tabular}{llllll}
\hline & & & Estimate & S.E. & P \\
\hline SAD. & $<---$ & R. & 0.637 & 0.106 & 0.000 \\
AS. & $<---$ & R. & 0.843 & 0.247 & 0.000 \\
SAD. & $<---$ & SE. & 0.128 & 0.065 & 0.050 \\
AS. & $<---$ & SE. & 0.225 & 0.260 & 0.000 \\
SAD. & $<---$ & C. & 0.093 & 0.069 & 0.175 \\
AS. & $<---$ & C. & 0.898 & 0.188 & 0.000 \\
CD. & $<---$ & AS. & 0.499 & 0.081 & 0.000 \\
CD. & $<---$ & SAD. & 0.774 & 0.125 & 0.000 \\
\hline
\end{tabular}

The SR Model Supported H1a, H2a, H2b, H3a, H3b, H4 and H5 as exhibited in table 3. The results in table demonstrated that Reactance has positive relationship with Social Ad Skepticism (unstandardized $\beta=0.637$; S.E $=0.106 p=0.000)$, Reactance has significantly associated with Ad Skepticism and has positive relationship (unstandardized $\beta=0.843$; $\mathrm{S} . \mathrm{E}=0.247 ; \mathrm{p}=0.000$ ) and Self Esteem is also positively associated with Social Ad Skepticism (unstandardized $\beta=0.128 ; \mathrm{S} . \mathrm{E}=0.065 ; \mathrm{p}=0.000$ ), similarly, Self Esteem is also positively associated with Ad Skepticism (unstandardized $\beta=0.225$; S.E = $0.260 ; p=0.000)$. However, no support was found for the impact of Cynicism on Social Ad Skepticism (unstandardized $\beta=0.093$; S.E $=0.069, p=0.175$ ) but Cynicism has positive significant influence on Ad Skepticism (unstandardized $\beta=0.898$; S.E $=0.188, p=0.000$ ). Results also have shown that Ad Skepticism has significantly positive influence on customer disengagement (unstandardized $\beta=0.499$; $\mathrm{S} . \mathrm{E}=0.08, \mathrm{p}=0.000)$ and also Social Ad Skepticism has significantly positive influence on customer disengagement (unstandardized $\beta=0.774$; S.E $=0.125 \mathrm{p}=0.000$ ).

\section{Discussion and Future Research Directions}

This research work is conducted to better understand the effect of general ad and social ad skepticism effect on customer disengagement. Customer disengagement by itself is an unexplored area; however disengagement construct is studied in many other areas of studies. This research has taken the response from the walk-in customers who visited telecom service providers either on their Business Centers or Franchises and banking branches which deal with the virtual currency in Pakistan. Results have supported the given hypotheses except cynicism effect on the social ad skepticism. The H1a Cynicism has positive effect on Ad Skepticism has been supported which manifest that there are customers in Pakistani virtual currency market who have suspiciousness and that suspiciousness has lead them to have disbeliefs in ads. H1b Cynicism has positive effect on Social Ad Skepticism has not been supported by results; the reason could be that Pakistan is less developed country, market and industry is not so mature in rules and regulation. Social thinking process is a step ahead than the customer's own interest protection, when customer is unable to defend his own interest, he/she would not go for any suspiciousness and disbeliefs in social ads. There can be another reason of this that usually social aspects in Pakistan are considered as the charity. Being Muslim, customers consider it as mandatory and pious act because of this their mind does not allow them to go for any suspension or disbeliefs.

Self-esteem is considered to reflect once own self, our hypotheses H2a Self-esteem has positive effect on Ad Skepticism and H2b Self-esteem has positive effect on Social Ad Skepticism are supported. Results shows that customer's self leads to disbeliefs in adverting either general or social, this can be because of the social and environmental influences on the individual personality. The uncertainty and self-confidence is less in the society and the go for the disbeliefs instead of taking more efforts to clear the vague situations. Hofstede (2006) found Pakistani individual on 70 in uncertainty avoidance index which also disclose that Pakistani society is avoiding the uncertainty. 
Individual freedom or choices are restricted in getting the desired and mandatory information is supported in our results. H3a Reactance has positive effect on Ad Skepticism and H3b Reactance has positive effect on Social Ad Skepticism confirm that customers in Pakistani telecom service sector are having reactance which is positively affecting the ad skepticism. H5 Ad Skepticism has positive effect on Customer Disengagement and H6 Social Ad Skepticism has positive effect on Customer Disengagement are also supported, this confirm that our suggested theoretical model is valid and it can be retested in other cultures and more mature markets where customers are more aware and governmental policies are strictly implemented. It can be proposed for such markets that there results would be more rigorous as previous researches illustrate the strong correlation of high education (Bell et al., 2013; Lay et al., 2013), more knowledge about product (Asimakopoulos \& Dix, 2013; Reijmersdal et al., 2013) leads to more disbeliefs which will lead to more customer disengagement.

This same model can be further tested through international and green ad skepticism in developing or developed market. The educational and gender and intergenerational influences effects are not tested in this research which could be tested in future research studies. Social disengagement leads to quite from society and sometimes the suicide (Scott, 2013), same way customer disengagement may lead to certain behaviors which can be dug in future research. The results manifest that virtual currency customers are having ad skepticism and that is becoming the cause of their disengagement to virtual currency brands. Further, social ad skepticism has more impact on the customer disengagement than the general ad skepticism. While the reactance has more effect on general ad skepticism than other antecedents and cynicism has the lowest impact on social ad skepticism than other antecedents.

\section{Practical Implication}

This study has theoretical and empirical contribution in the field of Marketing. The theoretical model is developed by mining the literature in an unexplored area. While constructs, which influence disengagement are tested by collecting primary data form the service sector where customer is also concerned with the peripheral part with the core benefits. The managers try to enhance the customer engagement however they usually keep less interest to save customers from disengagement; through this research work they can understand the customer disengagement and the influence of ad skepticism. They can decrease the customer disengagement by understanding the customers' level of disbeliefs. In Pakistani context, this research work has a lot of worth as this study focuses the sector which has great contribution in GDP. The contribution of service sector in Pakistan GDP is increased and in 2012 it is reached at 54.4 percent which value Rs.1.44 trillion to the economy (IQBAL, 2012). It grew 4.86 in 2012-13 and 4.9 in 2013-14 (Dawan, 2014). It confirms that more emphasis should be focused this sector which could be a competitive advantage for Pakistan economy. This research work has also tried to investigate the customers' skepticism and skepticism effect on customer disengagement. The results found Pakistani customer as skeptic and they are on the stage of disengagement. The managers should understand the situation and take certain steps to avoid the customers from disengagement.

\section{Research Limitation}

The models of (Obermiller \& Spangenberg, 1998; Thakor \& Goneau-Lessard, 2009) have identified the two main antecedent factors of ad skepticisms which are personality variables and consumption/influencing variables. In this research we have only tested the personality variables as antecedents in future research consumption/influencing variables can be tested. Data is collected form only one sector which is telecom and banking and only services are analyzed, the product side is still vacant to be researched. If they were analyzed in the research, it would have more practical approach. Sample used in this study is enough for statistical analysis but for further generalization, it may be increased. 


\section{Conclusion}

This study is conducted to know the antecedents and consequences of ad skepticism while this research work is also having industrial importance to regarding customer engagement. Engaging customer is the burning issue for companies especially the service sector, either online or offline. Minimizing the customer disengagement is same like reducing dissatisfaction or churn. Customer disengagement may be caused by many factors, ad skepticism is one of them; ad skepticism has two main antecedents personality variable and consumption/influencing variables. This research explores the relation of ad skepticism with customer disengagement through personality variables which are cynicism, reactance and self-esteem. The unit of analysis is the telecom and banking industry of Pakistan which is foreseeing an era of virtual currency and both are customer oriented industries. Only offline disengagement is researched and data is collected from the Business centers of telecom and banking branches dealing with virtual currency in Pakistan. Hypothetical model is given after digging the relevant literature; model is tested through confirmatory factor analysis and structural equation modeling. Eight hypotheses were purposed from the connections of model, all hypotheses are accepted except the cynicism positive effect on social ad skepticism. This can be due to commonality of social and charity in Pakistani society, Muslims consider charity as a pious act and they do not think for cynic behavior in charity or social related works. The results manifest that customers in telecom industry are having ad skepticism and that is becoming the cause of their disengagement. Further, social ad skepticism has more impact on the customer disengagement than the general ad skepticism. While the reactance has more effect on general ad skepticism than other antecedents and cynicism has the lowest impact on social ad skepticism than other antecedents.

\section{References}

Aquino, K., Reed II, A., Thau, S., \& Freeman, D. (2007). A grotesque and dark beauty: How moral identity and mechanisms of moral disengagement influence cognitive and emotional reactions to war. Journal of Experimental Social Psychology, 43(3), 385-392.

Asimakopoulos, S., \& Dix, A. (2013). Forecasting support systems technologies-in-practice: A model of adoption and use for product forecasting. International Journal of Forecasting, 29(2), 322-336.

Barksdale, H. C., \& Darden, W. R. (1972). Consumer attitudes toward marketing and consumerism. The Journal of Marketing, 28-35.

Bell, R. A., Grzywacz, J. G., Quandt, S. A., Neiberg, R., Lang, W., Nguyen, H., . . Arcury, T. A. (2013). Medical Skepticism and Complementary Therapy Use among Older Rural AfricanAmericans and Whites. Journal of health care for the poor and underserved, 24(2), 777-787.

Berman, E. M. (1997). Dealing with cynical citizens. Public Administration Review, 105-112.

Blakely, D. P., Wright, T. J., Dehili, V. M., Boot, W. R., \& Brockmole, J. R. (2012). Characterizing the time course and nature of attentional disengagement effects. Vision research, 56, 38-48.

Boush, D. M., Friestad, M., \& Rose, G. M. (1994). Adolescent skepticism toward TV advertising and knowledge of advertiser tactics. Journal of consumer research, 165-175.

Brehm, J. W. (1966). A theory of psychological reactance. New York.

Brehm, S. S., \& Brehm, J. W. (1981). Psychological reactance: A theory of freedom and control: Academic Press New York.

Brodie, R. J., Ilic, A., Juric, B., \& Hollebeek, L. (2011). Consumer engagement in a virtual brand community: An exploratory analysis. Journal of Business Research.

Buboltz Jr, W. C., Williams, D. J., Thomas, A., Seemann, E. A., Soper, B., \& Woller, K. (2003). Personality and psychological reactance: extending the nomological net. Personality and Individual Differences, 34(7), 1167-1177.

Campbell, M. C., \& Kirmani, A. (2000). Consumers' use of persuasion knowledge: The effects of accessibility and cognitive capacity on perceptions of an influence agent. Journal of consumer research, 27(1), 69-83.

Chylinski, M., \& Chu, A. (2010). Consumer cynicism: antecedents and consequences. European Journal of Marketing, 44(6), 796-837. 
Dahlen, M., Lange, F., Sjodin, H., \& Torn, F. (2005). Effects of Ad-Brand Incongruence. Journal of Current Issues \& Research in Advertising, 27(2), 1-12.

Dawan. (2014). Revenue, GDP Growth Targets Retrieved 09-06-2014, 2014, from http://epaper.dawn.com/?page=02 062014001

de Araujo, P., \& Lagos, S. (2013). Self-esteem, education, and wages revisited. Journal of Economic Psychology, 34, 120-132.

Donnell, A. J., Thomas, A., \& Buboltz Jr, W. C. (2001). Psychological reactance: Factor structure and internal consistency of the questionnaire for the measurement of psychological reactance. The Journal of social psychology, 141(5), 679-687.

Foley, D. (2004). Ogbu's theory of academic disengagement: its evolution and its critics. Intercultural Education, 15(4), 385-397.

Gana, K., Saada, Y., Bailly, N., Joulain, M., Hervé, C., \& Alaphilippe, D. (2013). Longitudinal factorial invariance of the Rosenberg self-esteem scale: Determining the nature of method effects due to item wording. Journal of Research in Personality, 47(4), 406-416.

Gaski, J. F., \& Etzel, M. J. (1986). The index of consumer sentiment toward marketing. The Journal of Marketing, 50(3), 71-81.

Goode, S. (2012). Engagement and Disengagement in Online Service Failure: Contrasting Problem and Emotional Coping Effects. Journal of Internet Commerce, 11(3), 226-253.

Haenlein, M., \& Kaplan, A. M. (2009). Unprofitable customers and their management. Business Horizons, 52(1), 89-97.

Hair, J., Black, W., Babin, B. Y. A., Anderson, R., \& Tatham, R. (2010). Multivariate Data Analysis. A Global Perspective: Pearson Prentice Hall.

Hameed, I., Roques, O., \& Arain, G. A. (2013). Nonlinear moderating effect of tenure on organizational identification (OID) and the subsequent role of OID in fostering readiness for change. Group \& Organization Management, 38(1), 101-127.

Hofstede, G. (2006). What did GLOBE really measure? Researchers' minds versus respondents' minds. Journal of International Business Studies, 37(6), 882-896.

Hollebeek, L. D. (2011). Demystifying customer brand engagement: Exploring the loyalty nexus. Journal of Marketing Management, 27(7-8), 785-807.

Hollebeek, L. D. (2013). The customer engagement/value interface: An exploratory investigation. Australasian Marketing Journal (AMJ), 21(1), 17-24.

IQBAL, S. (2012). Services' share in GDP rises to 54.4pc Retrieved 07-12-2013, 2013, from http://www.dawn.com/news/737922/

Jonas, E., Graupmann, V., Kayser, D. N., Zanna, M., Traut-Mattausch, E., \& Frey, D. (2009). Culture, self, and the emergence of reactance: Is there a "universal" freedom? Journal of Experimental Social Psychology, 45(5), 1068-1080.

Kanter, D. L., \& Wortzel, L. H. (1985). Cynicism and alienation as marketing considerations: some new ways to approach the female consumer. Journal of Consumer Marketing, 2(1), 5-15.

Khuhro, R. A., Bhutto, N. A., \& Sarki, I. H. (2015). Failure of Brand Intoxication with the Mediating Effect of Ad Skepticism. Sukkur IBA Journal of Management and Business, 2(1), 86-103.

Kwon, S. J., \& Chung, N. (2010). The moderating effects of psychological reactance and product involvement on online shopping recommendation mechanisms based on a causal map. Electronic Commerce Research and Applications, 9(6), 522-536.

Lau, R. R. (1985). Two explanations for negativity effects in political behavior. American Journal of Political Science, 29(1), 119-138.

Lay, G. C., Ahmad, R., \& Ming, B. H. (2013). The barriers to adoption of green Technoloy by higher education institutions in Malaysia. Malaysian Online Journal of Educational Management, 1(3), 2334.

Lee, G., \& Lee, W. J. (2009). Psychological reactance to online recommendation services. Information \& Management, 46(8), 448-452.

Macaskill, A. (2007). Exploring religious involvement, forgiveness, trust, and cynicism. Mental Health, Religion and Culture, 10(3), 203-218. 
Morris, M. (2011). Coping with cynicism: ROUTLEDGE JOURNALS, TAYLOR \& FRANCIS LTD 4 PARK SQUARE, MILTON PARK, ABINGDON OX14 4RN, OXFORDSHIRE, ENGLAND.

Muehling, D. D. (1987). Comparative advertising: The influence of attitude-toward-the-ad on brand evaluation. Journal of Advertising, 16(4), 43-49.

Newman, P., Kenworthy, J., \& Vintila, P. (1995). Can we overcome automobile dependence?: Physical planning in an age of urban cynicism. Cities, 12(1), 53-65.

Obermiller, Spangenberg, E., \& MacLachlan, D. L. (2005). Ad skepticism: The consequences of disbelief. Journal of Advertising, 34(3), 7-17.

Obermiller, \& Spangenberg, E. R. (1998). Development of a scale to measure consumer skepticism toward advertising. Journal of Consumer Psychology, 7(2), 159-186.

Obermiller, \& Spangenberg, E. R. (2000). On the origin and distinctness of skepticism toward advertising. Marketing Letters, 11(4), 311-322.

PakTribune. (2005). Soomro Deplores Publication Of Blasphemous Cartoons Retrieved 07-12-2013, 2013, from http://www.paktribune.com/news/print.php?id=134362

Pech, R., \& Slade, B. (2006). Employee disengagement: is there evidence of a growing problem? Handbook of Business Strategy, 7(1), 21-25.

Perrien, J., Paradis, S., \& Banting, P. M. (1995). Dissolution of a relationship: the salesforce perception. Industrial Marketing Management, 24(4), 317-327.

Reijmersdal, E. A., Tutaj, K., \& Boerman, S. C. (2013). The effects of brand placement disclosures on skepticism and brand memory. Communications, 38(2), 127-146.

Schade, J., \& Baum, M. (2007). Reactance or acceptance? Reactions towards the introduction of road pricing. Transportation Research Part A: Policy and Practice, 41(1), 41-48.

Schreiber, J. B., Stage, F. K., King, J., Nora, A., \& Barlow, E. A. (2006). Reporting Structural Equation Modeling and Confirmatory Factor Analysis Results: A Review. The Journal of Educational Research, 99(6), 323-337.

Scott, T. (2013). Sudden death liminality: Dehumanisation and disengagement. International Emergency Nursing, 21(1), 10-16.

Singh, S., Kristensen, L., \& Villasenor, E. (2009). Overcoming skepticism towards cause related claims: the case of Norway. International Marketing Review, 26(3), 312-326.

Taylor, V. A., \& Bearden, W. O. (2003). Ad spending on brand extensions: Does similarity matter? The Journal of Brand Management, 11(1), 63-74.

Thakor, M. V., \& Goneau-Lessard, K. (2009). Development of a scale to measure skepticism of social advertising among adolescents. Journal of Business Research, 62(12), 1342-1349.

Thornberg, R., \& Jungert, T. (2013). Bystander behavior in bullying situations: Basic moral sensitivity, moral disengagement and defender self-efficacy. Journal of Adolescence, 36(3), 475-483.

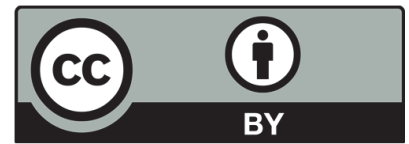

(C) 2017 by the authors; licensee Growing Science, Canada. This is an open access article distributed under the terms and conditions of the Creative Commons Attribution (CC-BY) license (http://creativecommons.org/licenses/by/4.0/). 